Review

\title{
Chagas Disease, Leishmaniasis, and Malaria in Solid Organ Transplant Recipients
}

Spinello Antinori ${ }^{1,2, *}$, Laura Milazzo ${ }^{2}$

1. Department of Biomedical and Clinical Sciences "Luigi Sacco", University of Milan, Via GB Grassi 74, Milan, Italy; E-Mail: spinello.antinori@unimi.it

2. III Division of Infectious Diseases, ASST Fatebenefratelli Sacco, Luigi Sacco Hospital, Via GB Grassi 74, Milan, Italy; E-Mail: laura.milazzo@unimi.it

* Correspondence: Spinello Antinori; E-Mail: spinello.antinori@unimi.it

Academic Editor: Maricar Malinis

Special Issue: Diagnosis and Management of Infections in Solid Organ Transplant Recipients

OBM Transplantation

2019 , volume 3 , issue 1

doi:10.21926/obm.transplant.1901039
Received: October 28, 2018

Accepted: January 02, 2019

Published: January 15, 2019

\begin{abstract}
Solid organ transplantation (SOT) is increasingly employed worldwide to treat several diseases causing both acute and chronic organ failure. Recipients of SOT are at an increased risk to develop infections as a consequence of immunosuppressive therapy. Sometimes such infections may be acquired by the transplanted organ or by reactivation of a previously acquired latent infection. The globalization and the increase of international travel poses a risk for exposure to infections such as Chagas disease (CD), leishmaniasis, and malaria endemic in tropical and subtropical areas of the world. We have reviewed the literature regarding risk factors, clinical presentation, diagnosis, and treatment of $C D$, leishmaniasis, and malaria in the setting of SOT.
\end{abstract}

\section{Keywords}

Chagas disease; leishmaniasis; malaria; solid organ transplantation; Trypanosoma cruzi; Leishmania infantum; Plasmodium falciparum; Plasmodium vivax ; review

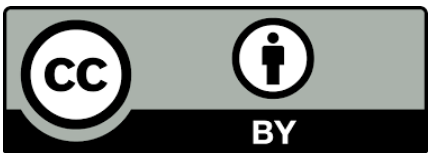

(C) 2019 by the author. This is an open access article distributed under the conditions of the Creative Commons by Attribution License, which permits unrestricted use, distribution, and reproduction in any medium or format, provided the original work is correctly cited. 


\section{Introduction}

The role of protozoan infections among solid organ transplant (SOT) patients is becoming increasingly recognised in both endemic and non-endemic countries, although these infections are generally considered rare [1-3].

Diagnosis and treatment of infections such as Chagas disease, malaria, and leishmaniasis in the setting of SOT is challenging due to multiple factors; to help clinicians to properly manage them, several guidelines and recommendations have been published in recent years [4-9]. The use of immunosuppressive drugs in transplant patients means that such protozoan infections not only can be acquired de-novo (by vectors, transfusion, and the organ transplanted), but can also undergo reactivation in those with latent infection due to the induced immunosuppression.

In the present review, we consider risk factors, clinical presentations, diagnosis, and treatment regarding Chagas disease (American trypanosomiasis), leishmaniasis, and malaria in the setting of SOT recipients with perspectives of how to screen and follow-up latent infections.

\section{Chagas Disease}

\subsection{Introduction}

Chagas disease $(C D)$, or American trypanosomiasis, is a protozoan infection caused by Trypanosoma cruzi. Initially described by Carlos Chagas in Brazil at the beginning of $20^{\text {th }}$ century, it is widespread and endemic in Mexico as well as Central and South America, where 6 million people are infected and 65 million people at risk of contracting the infection [10]. However, the huge migration from Latin America to the United States and Europe has driven the emergence of $C D$ in these countries with an estimated 68,000-122,000 cases in Europe and 300,000 in the United States [11-13]. A recent systematic review and meta-analysis showed a pooled prevalence of $C D$ of $4.2 \%$ in five European countries, with the highest one (18.1\%) found among Bolivian immigrants [14].

Although $C D$ has been considered a vector-borne disease transmitted to humans by hematophagous triatomine bugs (known as "kissing bugs"), the parasite can also be transmitted from a mother to her newborn, by transfusion of infected blood, the oral route, and by organ transplantation [15]. The first evidence of possible CD transmission by organ transplantation was during the early 1980s in Brazil and Chile $[16,17]$. In the United States, the first reported case of donor-derived CD was in 2001 [18]. Since then, CD has been reported in kidney, liver, heart, and lung recipients [19-22].

CD in SOT recipients can occur through three possible mechanisms: 1) transmission from chronically infected donors, 2) reactivation of latent infection in the recipient, or 3 ) infection acquired after transplant due to endemic exposure or possibly from transfusion of infected blood product.

\subsection{Risk of Transmission by Infected Donor}

The assessment of the risk of transmission of $C D$ by organ transplantation from seropositive donor $(D+)$ to seronegative recipient ( $R-)$ is based on a limited number of studies, which are generally retrospective and with short follow-up, as seen in Table 1 [21-30]. The average 
prevalence was $19.3 \%$, ranging from $9.6 \%$ for kidney transplant, $17.1 \%$ for liver transplant, to $75 \%$ for heart transplant [24, 27-30]. It is worth noting that in Argentina, the prevalence of $T$. cruzi infection among effective donors doubled (from 2.46\% to 4.6\%) from 2005 to 2009 [31]. A risk that is not negligible was also observed in Brazil, where among 2,822 potential organ donors, $1.3 \%$ had a positive $T$. cruzi serology, and the prevalence rate increased from $1.0 \%$ in 2010 to $1.6 \%$ in 2015 [32].

Table 1 Transmission from Trypanosoma cruzi seropositive donors to seronegative recipients (case studies and cohort studies).

\begin{tabular}{|c|c|c|c|c|c|c|c|}
\hline Organ & $\begin{array}{l}\text { Author/Ref } \\
\text { erence }\end{array}$ & $\begin{array}{l}\text { Country of } \\
\text { transplant }\end{array}$ & $\mathbf{N}(\%)$ & Prophylaxis & $\begin{array}{l}\text { Parasit } \\
\text { aemia } \\
\text { after } \\
\text { transpl } \\
\text { ant }\end{array}$ & $\begin{array}{l}\text { Time } \\
\text { onset, } \\
\text { median } \\
\text { (range) }\end{array}$ & $\begin{array}{l}\text { Outcome } \\
\mathrm{N}^{\circ} \\
\text { deaths } / \mathrm{N}^{\circ} \\
\text { patients } \\
(\%)\end{array}$ \\
\hline \multirow[t]{5}{*}{ Kidney } & Riarte/[23] & Argentine & $\begin{array}{l}3 / 16 \\
(18.7)\end{array}$ & No & $3 / 3$ & $\begin{array}{l}60 \text { (37- } \\
165) \text { days }\end{array}$ & $\begin{array}{l}1 / 16(6.2) \\
\text { unrelated } \\
\text { to } C D\end{array}$ \\
\hline & Sousa/[24] & Brazil & $0 / 9(0)$ & Yes & $0 / 9$ & Nihl & $0 / 10$ \\
\hline & Huprikar/[21] & USA & $\begin{array}{l}2 / 16 \\
(12.5)\end{array}$ & No & $2 / 2$ & $\begin{array}{l}11 \text { weeks } \\
(5-17)\end{array}$ & $\begin{array}{l}3 / 16 \\
(18.7)\end{array}$ \\
\hline & Cicora/[25] & Argentine & $0 / 6(0)$ & No & $0 / 6$ & Nihl & NR \\
\hline & Cura/[26] & Argentine & $1 / 15(6.7)$ & No & NR & NR & NR \\
\hline \multirow[t]{7}{*}{ Liver } & Barcan/[19] & Argentine & $1 / 1(100)$ & No & $1 / 1$ & 84 days & $\begin{array}{l}1 / 1(100) \\
\text { unrelated } \\
\text { to } C D\end{array}$ \\
\hline & $\begin{array}{l}\text { D'Albuquer } \\
\text { que/[27] }\end{array}$ & Brazil & $0 / 6(0)$ & Yes & $0 / 6$ & Nihl & $\begin{array}{l}2 / 6(33.3) \\
\text { unrelated } \\
\text { to } C D\end{array}$ \\
\hline & Salvador/[28] & Spain & $0 / 2(0)$ & Yes & $0 / 2$ & Nihl & $\begin{array}{l}1 / 2(50) \\
\text { unrelated } \\
\text { to } C D\end{array}$ \\
\hline & $\begin{array}{l}\text { McCormack } \\
/[29]\end{array}$ & Argentine & $2 / 9(22.2)$ & Yes & $2 / 9$ & 3 months & $\begin{array}{l}2 / 9(22.2) \\
\text { unrelated } \\
\text { to } C D\end{array}$ \\
\hline & Cura/[26] & Argentine & $5 / 10(50)$ & No & $2 / 2$ & 39,5 days & NR \\
\hline & Huprikar/[21] & USA & $2 / 9(22.2)$ & No & $1 / 1$ & 10 weeks & $\begin{array}{l}3 / 11 \\
(27.3)\end{array}$ \\
\hline & $\begin{array}{l}\text { Balderramo } \\
/[30]\end{array}$ & Argentine & $0 / 4(0)$ & Yes & $0 / 4$ & Nihl & $1 / 4(25)$ \\
\hline Heart & Huprikar/[21] & USA & $3 / 4(75)$ & No & $1 / 1$ & $\begin{array}{l}7 \text { weeks } \\
(3-9)\end{array}$ & $2 / 4(50)$ \\
\hline \multirow[t]{2}{*}{ Lung } & Huprikar/[21] & USA & $1 / 1(100)$ & No & $1 / 1$ & $\mathrm{NR}$ & $0 / 1$ \\
\hline & Cura/[26] & Argentine & $1 / 1(100)$ & No & $1 / 1$ & 73 days & $0 / 1$ \\
\hline Total & & & $\begin{array}{l}21 / 109 \\
(19.3)\end{array}$ & $\begin{array}{l}\text { 5/11 (45.5) } \\
\text { studies* }\end{array}$ & $\begin{array}{l}14 / 48 \\
(29.2)\end{array}$ & & $\begin{array}{l}16 / 81 \\
(19.7)\end{array}$ \\
\hline
\end{tabular}

*References [21] and [26] are counted once; NR, not reported 


\subsection{Risk of Reactivation in Infected Recipients}

Risk of reactivation of $T$. cruzi infection varies according to the organ transplanted and the degree of drug immunosuppression, with the highest risk associated with heart transplantation (mean average of $44.9 \%$ ) and similar risk for kidney (21.7\%) and liver (33.3\%) transplantation, as shown in Table 2 [30,33-47]. The majority of the studies regarding reactivation came from Brazil and are related to patients who undergo heart transplantation, with a prevalence rate ranging from $23 \%$ to $90 \%$ [33-41, 44]. In Brazil, end-stage Chagas cardiomyopathy $(\mathrm{CHC})$ is currently the third most common determinant for heart transplants (HTx), but it is also associated with a better outcome, with a 12-year survival rate of $46 \%[33,47]$. A recent study conducted in the United States between 2012-2016 showed a rate of reactivation of $61 \%$ among patients undergoing HTx [45]. In another study from the USA, the rate of reactivation after HTx was 45.5\% [46].

Table 2 Risk of reactivation of Chagas disease in seropositive transplant recipients.

\begin{tabular}{|c|c|c|c|c|c|c|}
\hline Organ & $\begin{array}{l}\text { Author/Refere } \\
\text { nce }\end{array}$ & $\begin{array}{l}\text { Country of } \\
\text { transplant }\end{array}$ & N (\%) & Prophylaxis & $\begin{array}{l}\text { Median time } \\
\text { of reactivation } \\
\text { (range) }\end{array}$ & $\begin{array}{l}\text { Outcome } \\
\mathrm{N}^{\circ} \\
\text { deaths/N} / \mathrm{N}^{\circ} \\
\text { patients } \\
(\%)\end{array}$ \\
\hline Kidney & Riarte/[23] & Argentine & $5 / 23(21.7)$ & No & $\begin{array}{l}63 \text { days (35- } \\
730)\end{array}$ & $1 / 23(4.3)$ \\
\hline Liver & Balderramo/[30] & Argentine & $3 / 9(33.3)$ & No & NR & $2 / 9(22.2)$ \\
\hline \multirow[t]{8}{*}{ Heart } & Stolf/[34] & Brazil & $3 / 4(75)$ & No & $\begin{array}{l}81 \text { days (59- } \\
420)\end{array}$ & NR \\
\hline & Bocchi/[35] & Brazil & $6 / 12(50)$ & $\begin{array}{l}\text { Yes (only } \\
\text { first period) }\end{array}$ & NR & NR \\
\hline & $\begin{array}{l}\text { de } \\
\text { Carvalho/[36] }\end{array}$ & Brazil & $3 / 10(30)$ & Yes & $\begin{array}{l}17 \text { months (2- } \\
23)\end{array}$ & $\begin{array}{l}3 / 10(30) \\
\text { unrelated } \\
\text { to } C D\end{array}$ \\
\hline & Bocchi/[37] & Brazil & $15 / 22(68)$ & & & $\begin{array}{l}9 / 22(40.9) \\
\text { at } 2 \text { years }\end{array}$ \\
\hline & De Souza/[38] & Brazil & $5 / 18(23)$ & No & NR & NR \\
\hline & Couto/[39] & Brazil & $16 / 24(67)$ & NR & NR & NR \\
\hline & Fiorelli/[40] & Brazil & $17 / 59(29)$ & Yes & NR & $\begin{array}{l}24 / 59 \\
(40.7) 1 \\
\text { death CDr }\end{array}$ \\
\hline & Bacal/[41] & Brazil & $21 / 39(53)$ & No & NR & $\begin{array}{l}5 / 39(12.8) \\
\text { at } 2 \text { years }\end{array}$ \\
\hline
\end{tabular}




\begin{tabular}{|c|c|c|c|c|c|c|}
\hline & Bestetti/[42] & Brazil & $9 / 10(90)$ & No & NR & $1 / 10(10)$ \\
\hline & Diez/[43] & Argentine & $5 / 10(50)$ & No & $\begin{array}{l}75 \text { days (32- } \\
92 \text { ) for clinical } \\
\text { manifestation; } \\
21 \text { days ( } 7-21 \text { ) } \\
\text { for kDNA-PCR }\end{array}$ & $\begin{array}{l}2 / 10(20) \\
\text { unrelated } \\
\text { to } C D\end{array}$ \\
\hline & Campos/[44] & Brazil & $17 / 64(26)$ & No & NR & NR \\
\hline & Kransdorf/[45] & USA & $5 / 11(45.5)$ & No & 23 days & $2 / 11(18.2)$ \\
\hline & Gray/[46] & USA & $19 / 31(61)$ & No & $\begin{array}{l}3 \text { weeks (<1-89 } \\
\text { weeks) }\end{array}$ & $\begin{array}{l}1 / 31(3.2) \\
\text { unrelated } \\
\text { to } C D\end{array}$ \\
\hline $\begin{array}{l}\text { Sub- } \\
\text { total* }\end{array}$ & & & $\begin{array}{l}141 / 314 \\
(44.9)\end{array}$ & & & \\
\hline Total & & & $\begin{array}{l}\text { 149/346(43. } \\
\text { 1) }\end{array}$ & & & $\begin{array}{l}50 / 224 \\
(22.3)\end{array}$ \\
\hline
\end{tabular}

NR, not reported; CD, Chagas disease; CDr, Chagas disease reactivation; KDNA PCR, polymerase chain reaction targeted to minicircle variable region; * referred to heart transplant

The 10-year survival rate of patients with HTx for CHC in the USA study was $57 \%$ and did not differ from the reported survival rate of patients with idiopathic dilated cardiomyopathy [48].

The use of mycophenolate mofetil (MMF) compared to azathioprine has been associated with a 6-fold higher risk of $T$. cruzi reactivation in a Brazilian retrospective study of HTx patients [41]. Another small study from Brazil reported a $90 \%$ reactivation rate among HTx patients treated with MMF, although the incidences of other post-transplant morbidities were similar in Chagas and non-Chagas disease patients [42].

\subsection{De Novo Post-Transplant Infection}

De novo acquisition of $C D$ in a seronegative recipient who had received an organ from a seronegative donor has been very rarely described but can occur from travel or residence in an endemic area as well as through blood transfusions [23, 49]. Riarte et al. reported two kidney transplant patients who were infected through the vector route and were diagnosed by seroconversion in the absence of any clinical manifestations [23].

\subsection{Clinical Presentation}

Acute CD has been diagnosed following kidney, heart, liver, and lung transplantation from $T$. cruzi seropositive donors; the clinical picture ranges from asymptomatic parasitaemia detected only by polymerase chain reaction (PCR) performed on peripheral blood samples to an acute disease presenting with daily high fever or with involvement and dysfunction of the kidney, heart, and brain [19, 20, 22, 23, 50, 51]. Besides fever in patients experiencing post-transplant acute infection several clinical pictures have been reported: acute chagasic myocarditis, cerebral 
trypanosomiasis with space-occupying brain lesions or kidney failure [18, 20, 51, 52]. In the above cited cases, trypomastigotes were identified in the bloodstream, peritoneal fluid, and cerebrospinal fluid, and T. cruzi amastigotes were found in endomyocardial biopsies [20, 51, 52]. In an autopsied kidney transplant recipient, disseminated CD was demonstrated with intense $T$. cruzi parasitism involving the heart, liver, spleen, kidney, bladder, and pancreas [51]. The median interval from transplantation to diagnosis of acute infection in a US study was 8 weeks, with a range of 3-29 weeks [21].

Reactivation of CD among seropositive recipients is currently diagnosed by detection of blood parasitaemia by polymerase chain reaction (PCR) or by endomyocardial biopsy (among HTx patients) which allows early preemptive therapy and improved survival $[36,43]$. The Chagas reactivation rate in patients who underwent $\mathrm{HTx}$ is reported on average to be $41 \%$, ranging from $23 \%$ to $90 \%$, depending on the study [32, 34, 36-46]. Multiple episodes of reactivation (up to eight) have been described among patients who underwent heart transplantation [40]. A parasitological response is generally rapidly achieved as documented by the absence of parasites by Strout analysis after one week of treatment, although using more sensitive methods such as KDNA PCR a negative results is observed between 1 and 2 weeks after treatment [26, 43]. Clinical manifestations include febrile illness, new onset of painful wine-colored nodules (metastatic chagomas) which can ulcerate, erythematous plaque or panniculitis, acute myocarditis, or tumorlike brain lesions mimicking toxoplasmosis or neoplastic processes [53-59]. Myocarditis and meningoencephalitis can run an aggressive course, rapidly leading to the death of the patients [5860]. Nevertheless, the outcome and survival rate of SOT recipients who develop acute CD or reactivation of the disease, especially among heart transplant recipients monitored and treated promptly, is similar to patients not affected by $C D$ and in some instances even better [23, 30, 33, 36, 37, 46]. Among liver transplant recipients in Argentina, the median stay in intensive care, median hospital stay, rate of acute graft rejection, rate of infection, and rate of graft survival was similar in patients at risk of CD compared to the controls, with no deaths attributable to acute CD [30]. Mortality related to CD reactivation among $\mathrm{HTx}$ recipients has been reported in $0.3 \%$ to $0.7 \%$ of patients in Brazil and in 0\% of patients in a recent study in the USA $[33,40,46]$.

\subsection{Diagnosis}

Diagnosis of chronic T. cruzi infection is achieved by two positive serology methods employing different antigens as recommended by the World Health Organization (WHO). A third test, such as immunoblotting with trypomastigote excreted-secreted antigen (TESA), is indicated when serology is inconclusive (one positive and one negative test) and to rule out cross-reactions (with Leishmania). PCR shows a low sensitivity due to low parasitaemia during chronic infection and should not be used as a screening test [61]. On the contrary, PCR for T. cruzi performed on blood is currently considered the gold standard for post-transplant monitoring and early diagnosis of acute infection or reactivation [26, 30, 43]. Quantitative real-time PCR monitoring during the first 6 to 24 months post-transplant is actually recommended and employed in the centers transplanting the organs of Chagas disease patients [1, 5, 9, 31, 45]. Direct parasitological examination (Strout method or blood smear) on peripheral blood, cerebrospinal fluid, or pericardial fluid as well as histopathology are less sensitive, although usually employed [20, 51, 52]. Blood culture and xenodiagnosis are also less sensitive and time-consuming methods. Interestingly, serological 
response in acute post-transplant $C D$ can be completely abrogated or can be delayed, and in patients with reactivated disease, a decrease of IgG1 and IgG3 titres has been shown [19, 23].

\subsection{Indication, Screening, and Management of Chagas Disease in SOT}

Recommendations regarding different aspects of CD and SOT (i.e., who should be transplanted, what organs from seropositive $T$. cruzi donors should be used or discarded, how to screen patients before and after transplantation, how to treat $C D$, etc.) have been released from Argentine, Brazil, Spain, the USA, and from a working group from Latin America, as shown in Table 3 [5, 6, 9, 31, 62].

Table 3 Chagas disease recommendations for Solid Organ Transplant recipients.

\begin{tabular}{|c|c|c|c|c|c|}
\hline $\begin{array}{l}\text { Country, } \\
\text { year, } \\
\text { reference }\end{array}$ & $\begin{array}{l}\text { Argentine, } \\
2010,[31]\end{array}$ & $\begin{array}{l}\text { USA, 2011, } \\
\text { [9] }\end{array}$ & Spain, 2011, [6] & $\begin{array}{l}\text { Latin America, } \\
\text { 2018, [5] }\end{array}$ & $\begin{array}{l}\text { Brazil,2016, } \\
{[62]}\end{array}$ \\
\hline $\begin{array}{l}\text { Pre- } \\
\text { transplan } \\
t \\
\text { screening } \\
\text { of } \\
\text { putative } \\
\text { recipients }\end{array}$ & $\begin{array}{l}\text { * All native } \\
\text { from Latin- } \\
\text { American } \\
\text { * born to Latin } \\
\text { American } \\
\text { mothers } \\
\text { * recipients of } \\
\text { unscreened } \\
\text { blood or blood } \\
\text { products } \\
{ }^{*} \text { resident or } \\
\text { traveller to } \\
\text { high risk areas } \\
\text { for }>6 \text { months }\end{array}$ & $\begin{array}{l}\text { * Universal } \\
\text { testing for } \\
\text { those born } \\
\text { in endemic } \\
\text { areas }\end{array}$ & $\begin{array}{l}\text { *Native population } \\
\text { from endemic areas } \\
\text { * Population who } \\
\text { have received a } \\
\text { blood transfusion in } \\
\text { endemic countries } \\
\text { * Offspring of } \\
\text { mothers who are } \\
\text { native from an } \\
\text { endemic country } \\
\text { and have a positive } \\
\text { or unknown } \\
\text { serology for Chagas } \\
\text { * Population who } \\
\text { have lived in an } \\
\text { endemic area fro } \\
\text { more than } 1 \text { month }\end{array}$ & $\begin{array}{l}\text { * Systematic } \\
\text { screening is } \\
\text { required for all } \\
\text { recipients at } \\
\text { risk for } T \text {. cruzi } \\
\text { infection } \\
\text { before } \\
\text { transplant }\end{array}$ & $\begin{array}{l}\text { * Screening } \\
\text { mandatory }\end{array}$ \\
\hline $\begin{array}{l}\text { Pre- } \\
\text { transplan } \\
t \\
\text { screening } \\
\text { of } \\
\text { putative } \\
\text { donors }\end{array}$ & $\begin{array}{l}\text { Same as for } \\
\text { putative } \\
\text { recipients }\end{array}$ & $\begin{array}{l}\text { Targeted } \\
\text { screening } \\
\text { for donors } \\
\text { born in } \\
\text { Latin } \\
\text { America }\end{array}$ & $\begin{array}{l}\text { Same as for } \\
\text { putative recipients }\end{array}$ & $\begin{array}{l}\text { * Systematic } \\
\text { screening is } \\
\text { required for all } \\
\text { donors at risk } \\
\text { for } T \text {. cruzi } \\
\text { infection } \\
\text { before } \\
\text { transplant }\end{array}$ & $\begin{array}{l}\text { * Screening } \\
\text { mandatory for } \\
\text { all donations } \\
\text { (use the same } \\
\text { algorithm for } \\
\text { blood } \\
\text { donations) }\end{array}$ \\
\hline $\begin{array}{l}\text { Which } \\
\text { tests } \\
\text { should be } \\
\text { used for } \\
\text { screening } \\
\text { Chagas } \\
\text { disease } \\
\end{array}$ & $\begin{array}{l}\text { Two } \\
\text { serological } \\
\text { tests using } \\
\text { different } \\
\text { methodologie } \\
\text { s }\end{array}$ & $\begin{array}{l}\text { Ortho EIA } \\
\text { and } \\
\text { Abbott } \\
\text { Prism } \\
\text { Chagas } \\
\text { tests }\end{array}$ & $\begin{array}{l}\text { Rapid serologic test } \\
\text { with high } \\
\text { sensitivity; } \\
\text { confirmation by } 2 \\
\text { specific serological } \\
\text { techniques } \\
\text { required }\end{array}$ & $\begin{array}{l}\text { Two different } \\
\text { serologic tests }\end{array}$ & $\begin{array}{l}\text { Two different } \\
\text { serologic tests }\end{array}$ \\
\hline Acceptan & Infected & Transplant & The heart and the & The decision to & Law restriction \\
\hline
\end{tabular}




\begin{tabular}{|c|c|c|c|c|c|}
\hline $\begin{array}{l}\text { ce of } \\
\text { organs } \\
\text { from } \\
\text { donor } \\
\text { with CD }\end{array}$ & $\begin{array}{l}\text { deceased } \\
\text { donors are } \\
\text { unacceptable } \\
\text { for heart } \\
\text { transplantatio } \\
\text { n. The } \\
\text { allocation of } \\
\text { other organs, } \\
\text { with } \\
\text { appropriate } \\
\text { informed } \\
\text { consent, could } \\
\text { be acceptable } \\
\text { for infected } \\
\text { recipients; for } \\
\text { uninfected } \\
\text { kidney } \\
\text { recipients and, } \\
\text { eventually, for } \\
\text { uninfected } \\
\text { lung and liver } \\
\text { recipients in } \\
\text { emergency } \\
\text { situations }\end{array}$ & $\begin{array}{l}\text { centers } \\
\text { can } \\
\text { consider } \\
\text { transplanti } \\
\text { ng kidneys } \\
\text { and livers } \\
\text { from } T \text {. } \\
\text { cruzi } \\
\text { infected } \\
\text { donors. } \\
\text { Rejection } \\
\text { of hearts } \\
\text { from } T \text {. } \\
\text { cruzi- } \\
\text { infected } \\
\text { donors. } \\
\text { Lung, } \\
\text { pancreas } \\
\text { and } \\
\text { intestine } \\
\text { can be } \\
\text { considered } \\
\text { with } \\
\text { caution. All } \\
\text { patients } \\
\text { should } \\
\text { provide } \\
\text { appropriat } \\
\text { e informed } \\
\text { consent } \\
\text { concerning } \\
\text { risk and } \\
\text { benefits }\end{array}$ & $\begin{array}{l}\text { intestines should } \\
\text { be excluded for } \\
\text { transplantation. For } \\
\text { the remaining } \\
\text { organs, } \\
\text { transplantation will } \\
\text { be possible subject } \\
\text { to the informed } \\
\text { consent of the } \\
\text { recipient (without } \\
\text { other options and } \\
\text { for urgency cases) }\end{array}$ & $\begin{array}{l}\text { accept an } \\
\text { organ from an } \\
\text { infected donor } \\
\text { is a balance } \\
\text { between } \\
\text { urgency of } \\
\text { need for the } \\
\text { organ and the } \\
\text { acceptance of } \\
\text { the risk of } \\
\text { possible } \\
\text { infection in the } \\
\text { recipient, both } \\
\text { by the medical } \\
\text { team and the } \\
\text { recipient } \\
\text { through } \\
\text { informed } \\
\text { consent, along } \\
\text { with the ability } \\
\text { to diagnose } \\
\text { and treat } \\
\text { infection if it } \\
\text { occurs }\end{array}$ & $\begin{array}{l}\text { on the use of } \\
\text { organs from } C D \\
\text { patients. The } \\
\text { team will } \\
\text { decide whether } \\
\text { the organ is } \\
\text { acceptable for } \\
\text { use or not } \\
\text { regarding } \\
\text { kidney, } \\
\text { kidney/pancrea } \\
\text { s, liver and lung } \\
\text { donations }\end{array}$ \\
\hline $\begin{array}{l}\text { Criteria } \\
\text { for } \\
\text { microbiol } \\
\text { ogic } \\
\text { diagnosis } \\
\text { of } \\
\text { reactivati } \\
\text { on }\end{array}$ & Not reported & $\begin{array}{l}\text { Not } \\
\text { reported }\end{array}$ & $\begin{array}{l}\text { * Positive Strout } \\
\text { method } \\
\text { * Positive PCR in } \\
\text { patients with } \\
\text { previous negative } \\
\text { PCR }\end{array}$ & $\begin{array}{l}\text { * Direct } \\
\text { detection of } T \text {. } \\
\text { cruzi in blood, } \\
\text { fluids and } \\
\text { tissues } \\
\text { * High levels of } \\
\text { quantitative } \\
\text { PCR }\end{array}$ & $\begin{array}{l}\text { * Direct } \\
\text { microscopic } \\
\text { detection of } T \text {. } \\
\text { cruzi in blood, } \\
\text { fluids and } \\
\text { tissues }\end{array}$ \\
\hline $\begin{array}{l}\text { Post- } \\
\text { transplan } \\
\text { t } \\
\text { monitori } \\
\text { ng of } \\
\text { patients } \\
\text { receiving }\end{array}$ & $\begin{array}{l}\text { Monitoring } \\
\text { weekly or } \\
\text { every } 2 \text { weeks } \\
\text { for the first } 6 \\
\text { months, } \\
\text { monthly } \\
\text { thereafter, }\end{array}$ & $\begin{array}{l}\text { Monitorin } \\
\text { g with } T \text {. } \\
\text { cruzi PCR } \\
\text { and } \\
\text { microscop } \\
\text { y of blood } \\
\text { specimens }\end{array}$ & $\begin{array}{l}\text { Parasitologic } \\
\text { studies } \\
\text { (quantitative PCR, } \\
\text { Strout method, } \\
\text { direct parasitologic } \\
\text { test according to } \\
\text { the possibilities of }\end{array}$ & $\begin{array}{l}\text { Monitoring } \\
\text { weekly during } \\
\text { the first } 2 \\
\text { months, every } \\
2 \text { weeks } \\
\text { through } \\
\text { months } 3 \text { to } 6 \text {, }\end{array}$ & $\begin{array}{l}\text { Sequential } \\
\text { parasitologic } \\
\text { monitoring in } \\
\text { the peripheral } \\
\text { blood, every } \\
\text { week for up to } \\
60 \text { days and }\end{array}$ \\
\hline
\end{tabular}




\begin{tabular}{|c|c|c|c|c|c|}
\hline $\begin{array}{l}\text { an organ } \\
\text { from an } \\
\text { infected } \\
\text { donor }\end{array}$ & $\begin{array}{l}\text { and weekly for } \\
2 \text { months after } \\
\text { intensification } \\
\text { of } \\
\text { immunosuppr } \\
\text { ession }\end{array}$ & $\begin{array}{l}\text { weekly for } \\
\text { the first } \\
\text { two } \\
\text { months, } \\
\text { every } 2 \\
\text { weeks } \\
\text { during the } \\
\text { third } \\
\text { month, } \\
\text { then } \\
\text { monthly } \\
\text { until at } \\
\text { least } 6 \\
\text { months } \\
\text { post- } \\
\text { transplant } \\
\text { ation }\end{array}$ & $\begin{array}{l}\text { the laboratory. } \\
\text { Weekly for } 2 \\
\text { months, bimonthly } \\
\text { between the } \\
\text { second and sixth } \\
\text { months post- } \\
\text { transplant, annually } \\
\text { thereafter }\end{array}$ & $\begin{array}{l}\text { and annually } \\
\text { thereafter or } \\
\text { at any time } \\
\text { after an } \\
\text { intensification } \\
\text { of } \\
\text { immunosuppr } \\
\text { ession }\end{array}$ & $\begin{array}{l}\text { indirect } \\
\text { parasitologic } \\
\text { and serology } \\
\text { examination on } \\
\text { days } 30 \text { and } 60 \\
\text { after } \\
\text { transplantation. } \\
\text { Thereafter, } \\
\text { clinical, } \\
\text { serologic and } \\
\text { parasitologic } \\
\text { (direct/indirect/ } \\
\text { PCR)examinatio } \\
\text { ns should be } \\
\text { performed } \\
\text { every two } \\
\text { months for up } \\
\text { to one year of } \\
\text { follow-up; then } \\
\text { every } 6 \text { months } \\
\text { for as long as } \\
\text { immunosuppres } \\
\text { sion persists }\end{array}$ \\
\hline $\begin{array}{l}\text { Prophyla } \\
\text { xis for } \\
\text { recipients } \\
\text { of } \\
\text { infected } \\
\text { organs }\end{array}$ & $\begin{array}{l}\text { The risk of } \\
\text { toxicity among } \\
\text { patients with } \\
\text { end-stage } \\
\text { renal disease } \\
\text { and liver } \\
\text { insufficiency, } \\
\text { seems to } \\
\text { outweight its } \\
\text { potential } \\
\text { benefit }\end{array}$ & $\begin{array}{l}\text { Prophylaxi } \\
\text { s not } \\
\text { recommen } \\
\text { ded }\end{array}$ & $\begin{array}{l}\text { Consider use of } \\
\text { post-transplant } \\
\text { prophylaxis or early } \\
\text { treatment of } \\
\text { reactivation }\end{array}$ & $\begin{array}{l}\text { Monitoring } \\
\text { preferred over } \\
\text { the use of } \\
\text { prophylaxis }\end{array}$ & $\begin{array}{l}\text { Monitoring } \\
\text { preferred over } \\
\text { the use of } \\
\text { prophylaxis. } \\
\text { Prophylaxis } \\
\text { indicated if the } \\
\text { sequence } \\
\text { monitoring is } \\
\text { not indicated }\end{array}$ \\
\hline
\end{tabular}

Chagas cardiomyopathy is not an absolute contraindication to heart transplantation, although some centers have adopted strict clinical and laboratory monitoring protocol to diagnose early, asymptomatic reactivation and early institution of treatment [45]. Similarly, patients with chronic indeterminate $C D$ are considered suitable candidates for other solid organ transplants. Spanish guidelines specifically contraindicate any type of transplant for patients with advanced megaesophagus or megacolon [6]. Serologic screening is recommended both for candidate donor and recipients who share epidemiologic risk factors for $C D$, such as those born in Latin America, those born in non-endemic countries by Latin American mothers, recipients of blood transfusions in endemic countries, and those who have resided or travelled in Latin America [5, 6, 9, 31].

All guidelines indicate the use of two serological techniques for confirming the diagnosis of $T$. cruzi infection, whereas US guidelines specifically recommend the use of an FDA-cleared test 
(Ortho EIA and Abbott Prism Chagas test) with additional testing by the Center for Disease Control (CDC) if a donor is found positive [9]. The use of organs from CD-infected donors is a matter of debate with absolute and relative contraindications; all guidelines absolutely contraindicate the use of the heart from a positive donor in positive or negative recipients $[5,6,9,31]$. This is the consequence of the high rate of $C D$ transmission with heart transplantation observed in a series of patients in which the CD diagnosis was discovered "a posteriori" [21]. This statement is in agreement with a recent autopsy study demonstrating the persistence of $T$. cruzi in $57.1 \%$ of heart samples [63].

In the same study, no samples from the lung, liver, kidney, pancreas, esophagus, or gastrointestinal tract were found to have the parasite as detected by histology, immunohistochemistry, or PCR. However, Spanish guidelines also recommend against the use of small bowel from infected donors [6]. In general, all guidelines indicate that liver and kidney transplants from positive donors can be made in cases of urgency, having obtained an appropriate informed consent concerning risk and benefits from the patient $[6,9,31]$.

All guidelines advise to monitor post-transplant patients with laboratory tests (quantitative PCR, Strout method) that are able to identify parasites in the bloodstream responsible for de novo acute infection or reactivation among infected recipients [5, 6, 9, 31]. Indications about timing are similar among the recommendations, with close monitoring during the first 6 months after transplantation and when an intensification of immunosuppressive drug regimen is needed (Table 3). Heart transplant patients are recommended closer and more prolonged parasitologic monitoring, including evaluation of endomyocardial biopsies [5, 6, 9, 31, 64].

As far prophylaxis, among recipients of infected organs and in patients with chronic CD, guidelines favour an approach based on careful monitoring over the use of prophylactic treatment because of lack of evidence and the potential of drug toxicity $[5,6,9]$.

In regard to immunosuppressive drug regimens, mycophenolate mofetil (MMF) should be avoided, especially in heart transplant recipients, and replaced by azathioprine or cyclosporine; when possible, antithymocyte globulin should also be avoided for rejection prevention [5, 6]. Basiliximab and daclizumab have been suggested as possible alternatives to MMF during the induction phase [6]. Moreover, based on an in vitro study showing activity against $T$. cruzi growth, rapamycin is indicated as another possible alternative to the use of $\operatorname{MMF}[5,6]$. Finally, it is recommended to maintain the immunosuppression at the lowest possible level, and a single retrospective study conducted in heart transplant recipients found patients receiving lower doses of cyclosporine (3-5 mg/ $\mathrm{kg}$ versus $5-10 \mathrm{mg} / \mathrm{kg}$ ) had significantly lower reactivation rates than those receiving higher doses of cyclosporine $[5,6,60]$.

Benznidazole $(5 \mathrm{mg} / \mathrm{kg} / \mathrm{day}$ ) is generally recommended as a first line drug for treatment of acute infection and reactivation for 30 or 60 days $[5,6,31]$. The choice of benznidazole is dictated by its better tolerability, although studies evaluating drug interactions with immunosuppressive drugs are lacking. In patients with renal or hepatic failure, no dose adjustment is needed. Nifurtimox (8-10 $\mathrm{mg} / \mathrm{kg} /$ day) is considered a second choice that requires a more prolonged administration (90 days). Both drugs are metabolised by cytochrome P450, thus, with possible increase of cyclosporine, tacrolimus, sirolimus, and everolimus blood levels [5]. A frequent monitoring of blood cell count is needed for both drugs because of potential myelosuppression $[5,6]$. Skin rash, peripheral neuropathy, insomnia, and gastrointestinal intolerance are other possible adverse effects associated with anti-trypanosomal drugs [5, 6]. 


\section{Leishmaniasis}

\subsection{Introduction}

Leishmaniasis refers to a group of vector-borne diseases caused by more than 20 Leishmania species belonging to the family Trypanosomatidae [65-67]. The natural reservoir of the parasite can be animal (zoonotic leishmaniasis) or human (anthroponotic leishmaniasis). The disease can present in four main forms: cutaneous leishmaniasis $(C L)$, mucocutaneous leishmaniasis (MCL), visceral leishmaniasis (VL), and post-kala-azar dermal leishmaniasis (PKDL). In 2015, according to the WHO, 87 and 75 countries were considered endemic for CL and VL, respectively, with almost 200,000 new cases of $C L$ and 25,000 new cases of VL [65].

SOT recipients can develop de novo Leishmania infection through vector transmission, reactivation of a latent infection, or acquire the infection by donated organ or blood transfusion, although this occurs less frequently $[68,69]$.

$\mathrm{VL}$ is the picture observed more frequently among SOT recipients whereas $\mathrm{CL}$ and $\mathrm{MCL}$ are only occasionally reported [68, 70-72]. Leishmaniasis is described predominantly among kidney transplant recipients in comparison with other SOT recipients, but it is presently unknown if this is due to an increased risk related to renal failure or dialysis or due to the fact that kidney transplants comprise the great majority of SOTs [65, 68, 73-75].

\subsection{Risk Factors}

Only few studies have evaluated seroprevalence of Leishmania infection among candidates for organ transplantation or recipients of SOT [74, 76-78]. A study from northeastern Brazil conducted among 310 haemodialysed patients showed a $22.3 \%$ reactivity to Leishmania by indirect fluorescence antibody test [74]. Another study from Brazil evaluating 50 liver recipients and 17 liver donors found a 1.5\% seroprevalence, but when polymerase chain reaction (PCR) was applied, $23.5 \%$ of donors and $8 \%$ of recipients resulted positive for PCR-specific Leishmania infantum either in blood, liver, or spleen samples [76]. In the USA, five out 48 (10.6\%) Hispanic transplant candidates had positive Leishmania antibody titres [77]. Finally, a study from southern Spain found a $4.8 \%$ prevalence of positive Leishmania antibodies from 625 asymptomatic renal transplant recipients [78]. A multicenter case-controlled study performed in Brazil and Spain found a 5.7-fold higher incidence of $\mathrm{VL}$ in the former country that has been explained by the higher incidence of $\mathrm{VL}$ in Brazil (1.8 cases per 100,000 inhabitants) in comparison with Spain (0.4 cases per 100,000 inhabitants) and by an earlier onset of the disease as a consequence of reactivation [79]. In the above cited study, high-dose prednisone in the preceding 6 months was the only independent risk factor significantly associated with development of VL (OR 2.5) [79].

Interestingly, a study conducted in Madrid during an outbreak of leishmaniasis found an annual risk of developing VL among SOT recipients 136 times higher compared to immunocompetent subjects living in the same area [80]. Three risk factors emerged as associated with the diagnosis of $\mathrm{VL}: 1$ ) living in close proximity to the area affected by the outbreak (relative risk $11.74 \%$ ), explained by a higher chance to be bitten by the infected phlebotomous; 2 ) receiving a SOT during the outbreak; and 3) being black from sub-Saharan Africa, with a relative risk of $6.40 \%$ [80]. The role of ethnicity and its possible association with VL needs to be explored in future studies, as black people emerged as the most affected in another study from Brazil [81]. 


\subsection{Clinical Presentation}

$\mathrm{VL}$ is by far the most frequently encountered clinical presentation of leishmaniasis among SOT recipients described in kidney, liver, heart, lung, and pancreas transplantation [7, 68, 79-81]. Fever is the most common symptom of VL, but in the study by Clemente et al., $14 \%$ of patients were afebrile [68, 79]. Visceromegaly (either hepatomegaly or splenomegaly) has been variably reported in the literature but is generally high (75-81\%), although only one-third of patients present with the classic triad of fever, visceromegaly, and pancytopenia [68, 79, 81]. The median time to diagnosis of VL after transplantation ranges from 11 months to 28 months, although in one study, one-third of patients were diagnosed within the first 6 months following transplantation [79, 81]. Active bleeding from the digestive tract was observed in $23 \%$ of patients and can be the mode of onset of the disease $[81,85]$. Septic shock has been reported in $8 \%$ of patients in one study [79]. Concurrent cutaneous and visceral leishmaniasis has been observed among kidney and liver transplant recipients and both typical and atypical presentation of $C L$ are reported in the literature [86-90]. Mucosal leishmaniasis localised on the tongue, lip, labial commissure, and nose has been described among SOT patients almost exclusively in the Mediterranean basin where the species responsible is $L$. infantum [68, 91-95]. Relapse of VL was reported in $26 \%$ to $28 \%$ of SOT patients and in one of these studies, more frequently among patients not receiving prophylaxis (34.8\%) than those receiving prophylaxis $(8.3 \%)$, with a $p$ value of $0.19[79,81]$. Relapse of $V L$ has been reported to occur among kidney transplant recipients in a period ranging from 1 month to 5 years after the initial diagnosis [95]. Multiple episodes of relapse, as observed in HIV-positive patients, can be diagnosed also among SOT recipients, although for those living in endemic areas it is difficult to rule out reactivation from reinfection [95].

\subsection{Diagnosis}

A direct diagnosis of leishmaniasis $(\mathrm{VL}, \mathrm{CL}, \mathrm{MCL})$ requires the demonstration of protozoa in biopsy samples from bone marrow or the spleen $(\mathrm{VL})$ or from skin ulcer or mucosal lesions. This task can be achieved by microscopy, culture, or molecular diagnosis. In the study by Clemente et al., the sensitivity of bone marrow microscopy for the diagnosis of VL was $80.6 \%$, better than the $75 \%$ achieved by polymerase chain reaction and the $56 \%$ achieved by culture [79]. However, in the same study, combining the three methods yielded a sensitivity of $89 \%$ [79]. Polymerase chain reaction (PCR) is considered the best available method for the diagnosis of $V L$, combining high sensitivity and specificity, rapid species identification, and the advantage of using peripheral blood samples (rather than bone marrow) with identical sensitivity and specificity [96]. However, the utilization of PCR in SOT is limited to few reported cases [79, 95, 97, 100]. Moreover, the problem of asymptomatic patients with positive PCR results needs to be considered because a threshold value capable of distinguishing this condition (asymptomatic parasitaemia) from the disease is presently unknown. It should be highlighted that in a recent case report of $V L$ in a lung transplant recipient using real-time PCR which targets the kinetoplastic DNA, the authors were able to retrospectively detect the DNA of the parasite months before the diagnosis, suggesting the possibility to adopt a preemptive approach [97]. Leishmania serology has been reported to be positive in $76 \%$ of SOT patients with VL, but it is unable to distinguish between prior exposure and 
active disease; additionally, in areas where Chagas disease coexists, cross-reactivity can be a problem because both parasites share antigens [7, 98].

\subsection{Screening and Management of Leishmaniasis}

Since there is not a clear demonstration of the utility of screening either among candidate organ transplant recipients or organ donors, available guidelines do not recommend this practice $[7,99,100]$. It is generally recommended that transplant recipients visiting endemic countries use insect repellent and avoid outdoor activities during the hours when sand flies are more active [7]. Liposomal amphotericin $B(L-A M B)$ is considered the drug of choice for the treatment of leishmaniasis in SOT with a cumulative dose of $40 \mathrm{mg} / \mathrm{kg}$ administered over 10 infusions (days 1-5 followed by one week administration for 5 times) [100]. The liposomal formulation of amphotericin B is generally well tolerated and is preferred over amphotericin B deoxycholate among SOT recipients $[79,81]$. In a review of the literature, the initial cure rate of VL among transplant recipients has been documented as $84 \%$ [68]. A Brazilian study conducted among kidney transplant recipients reported an $80 \%$ VL remission and return to dialysis in $33 \%$ of patients achieving VL remission [81]. Finally, in a Spanish-Brazilian study involving kidney, liver, heart, and lung transplant recipients, the cure rate at the one month follow-up was reported to be $94.2 \%$ [79].

Experience with miltefosine (the only available oral therapy for $\mathrm{VL}$ ) in the setting of SOT is limited to 6 patients in whom the drug was used as salvage treatment after first-line therapy with L-AMB [101]. Patients were treated with $2.5 \mathrm{mg} / \mathrm{kg} /$ day of miltefosine for 28 days but $50 \%$ relapsed after an initial clinical improvement. As commonly used in HIV-infected patients, a secondary prophylaxis seems to also be warranted among SOT recipients, although the interval and means of administration are presently unknown $[7,79]$. As far as the treatment of CL in SOT recipients, it is recommended to use the same systemic treatment (i.e. L-AMB) as for VL [7].

\section{Malaria}

\subsection{Introduction}

Malaria is the most common human protozoan disease worldwide caused by six different species of Plasmodium: Plasmodium falciparum, P. vivax, P. ovale wallikeri, P. ovale curtisi, $P$. malariae, and $P$. knowlesi, the latter being a zoonotic parasite emerging in East Asia [102]. The disease is usually transmitted by the bite of infected Anopheles mosquitoes, but transmission by blood (via transfusion or sharing of contaminated needles), by mother to child, or following organ transplantation is also possible [103-106]. Post-transplant malaria may be the consequence of a donor-derived infection, transmission by blood transfusion, recrudescence, or relapse of a previous infection in the transplant recipient [107-109].

\subsection{Donor Deferral and Screening}

There are no uniform recommendations about deferral of candidate donors who have resided or travelled in endemic areas for malaria. In general, most recommendations refer to adopted policies for exclusion of blood donors [110]. The European Society of Clinical Microbiology and Infectious Diseases (ESCMID) recommendations indicate screening with nucleic acid tests (NATs) in 
all donors and recipients who have resided or travelled to areas of malaria endemicity in the 3 preceding years [111]. If the donor's death is secondary to malaria, organs should be rejected [111]. Brazilian guidelines and the recently published guidelines from Latin America recommend routine screening for donors coming from endemic regions, based on annual parasite incidence (API), and excluding those with a diagnosis of malaria in the previous 12 months, with fever in the previous 30 days, or having returned from a city with a high API in the previous 30 days $[2,8]$. Candidate donors who had a history of $P$. malariae are permanently deferred from donation because this parasite probably persists for life, posing a risk even decades after a previous episode of apparently cured malaria, as observed in cases of transfusion-transmitted malaria [8, 103]. Moreover, potential donors with a diagnosis of active infection should be deferred from organ donation until the malaria is diagnosed and treated. All guidelines recommend the use of molecular screening with NATs which are able to detect low parasitaemia, a condition which can be missed by thick blood smears and rapid antigen tests that are considered insensitive $[2,8,111]$. Serology testing can be considered as a marker of previous exposure in the case of unclear donor travel history.

Even with the use of the most sensitive diagnostic test on blood, liver transplantation has been associated with the transmission of $P$. vivax due to the persistence of hepatic hypnozoites, which is also possible for $P$. ovale $[112,113]$. Several cases of multi-organ transmission of malaria from a single donor have been described $[107,114,115]$.

\subsection{Post-Transplant Management}

Malaria also carries a possible risk of recrudescence or reactivation among recipients with asymptomatic infection following immunosuppression [116]. For this reason, it has been suggested to prospectively monitor high risk patients (i.e., those coming from malaria-endemic areas) with PCR for a period of two months [117].

\subsection{Clinical Presentation}

Post-transplant malaria presents with high fever and chills that do not respond to empirical antibiotic therapy [107, 114, 115, 118-121]; thrombocytopenia and anemia are commonly observed as in the case of vector-borne malaria [114, 115, 118-121]. Mental impairment, coma, or acute renal failure may be observed as complications of $P$. falciparum malaria when the diagnosis is delayed $[115,118,119]$. Patients with a diagnosis of malaria after a liver transplant can display liver function deterioration with important increases of transaminases and bilirubin [107, 112, 115]. Malaria diagnosis in cases occurring through infected grafts is entertained after a median of 29.5 days [8]. Death of the patient was reported in $12 \%$ of cases recently reviewed, with the worst outcome among liver and heart transplant patients, although the overall low number of malaria cases prevent any definite conclusion [8].

\subsection{Diagnosis}

In all the reported cases of post-transplant malaria, the correct diagnosis was always achieved by conventional thick and thin smears of peripheral blood [8, 107, 112-115, 118-121]. Few cases of mixed infections caused by $P$. falciparum and $P$. vivax as well as by $P$. malariae and $P$. ovale were 
reported in the literature $[114,121]$. To the best of our knowledge, a very sensitive quantitative PCR for malaria has been used only in a single case of an allogenic haematopoietic stem cell transplant patient; it showed a long-term persistence of a positive PCR result ( $>30$ days) after therapy-induced resolution of symptoms and parasite disappearance detected by microscopy [109].

\subsection{Treatment}

Patients were treated according to the species of Plasmodium identified and the severity of the malaria picture observed [107-109, 112-115, 119-121]. There is an anecdotal report of two patients who underwent a pre-emptive treatment for malaria after the recognition of the disease in a recipient from the same organ donor [122]. Artesunate, the drug of choice for severe malaria, has been employed in a single case of malaria in a heart transplant patient [115].

The recommendations for treatment of malaria in SOT recipients are essentially the same as for the population of non-transplant patients [8].

\section{Conclusion}

In conclusion, although rarely observed, $C D$, leishmaniasis, and malaria pose a risk that is not negligible among SOT recipients, especially in the present era of globalisation. The awareness of this risk in recent years has led to the introduction of molecular tests in the clinical practice to screen both donors and recipients (especially for $C D$ ), and to promulgate recommendations and guidelines. The risk of reactivation is particularly important for $C D$, requiring PCR monitoring of the blood in order to make an early diagnosis and preemptive therapy. High quality studies are needed to accurately identify risk factors for $C D$ reactivation.

\section{Author Contributions}

Spinello Antinori conceived the paper, made the bibliography search, wrote the paper; Laura Milazzo made the bibliography search, wrote the paper.

\section{Funding}

No funding for this research.

\section{Competing Interests}

The authors have declared that no competing interests exist.

\section{References}

1. Kransdorf EP, Zakowski PC, Kobashigawa JA. Chagas disease in solid organ and heart transplantation. Curr Opin Infect Dis. 2014; 27: 418-424.

2. Clemente WT, Pierrotti LC, Abdala D, Morris MI, Azevedo LS, Lopez-Velez R, et al. Recommendations for management of endemic diseases and travel medicine in solid-organ transplant recipients and donors: Latin America. Transplantation. 2018; 102: 193-208. 
3. Fabiani S, Fortunato S, Bruschi F. Solid organ transplant and parasitic disease: a review of the clinical cases in the last two decades. Pathogens. 2018; 7: 65.

4. Nogueira SS, Felizado AA, Caldas IS, Goncalves RV, Novaes RD. Challenges of immunosuppressive and antitrypanosomal drug therapy after heart transplantation in patients with chronic Chagas disease: a systematic review of clinical recommendations. Transplant Rev. 2018; 32: 157-167.

5. Pierrotti LC, Carvalho NB, Amorin JP, Pascual J, Kotton CN, Lopez-Velez R. Chagas disease recommendations for solid-organ transplant recipients and donors. Transplantation. 2018; 102: S1-S7.

6. Pinazo MJ, Miranda B, Rodriguez-Villar C, Altclas J, Serra MB, Garcia-Otero EC, et al. Recommendations for management of Chagas disease in organ and hematopoietic tissue transplantation programs in nonendemic areas. Transplant Rev. 2011; 25: 91-101.

7. Clemente WT, Mourao PHO, Lopez-Medrano F, Schwartz BS, Garcia-Donoso C, Torre-Cisneros J. Visceral and cutaneous leishmaniasis recommendations for solid organ transplant recipients and donors. Transplantation. 2018; 102: S8-S15.

8. Pierrotti LC, Levi ME, Di Santi SM, Segurado AC, Petersen E. Malaria disease recommendations for solid organ transplant recipients and donors. Transplantation. 2018; 102: S16-S26.

9. Chin-Hong PV, Schwartz BS, Bern C, Montgomery SP, Kontak S, Kubak B, et al. Screening and treatment of Chagas disease in organ transplant recipients in the United States: recommendations from the Chagas in transplant working group. Am J Transplant. 2011; 11: 672-680.

10. World Health Organization. Chagas disease in Latin America: an epidemiological update based on 2010 estimates. Wkly Epidem Rec. 2015; 90: 33-44.

11. Antinori S, Galimberti L, Bianco R, Grande R, Galli M, Corbellino M. Chagas disease in Europe: a review for the internist in the globalized world. Eur J Intern Med. 2017; 43: 6-15.

12. Basile L, Jansa JM, Carlier $Y$, Salamanca DD, Angheben A, Bartoloni A, et al. Chagas disease in European countries: The challenge of surveillance system. Euro Surveill. 2011; 16.

13. Bern C, Montgomery SP. An estimate of the burden of Chagas disease in the United States. Clin Infect Dis. 2009; 49: e52-e54.

14. Requena-Mendez A, Aldasoro E, de Lazzari E, Sicuri E, Brown M, Moore DA, et al. Prevalence of Chagas disease in Latin-American migrants living in Europe: a systematic review and metaanalysis. Plos Neglect Trop Dis. 2015; 9: e0003540.

15. Perez-Molina JA, Molina I. Chagas disease. Lancet. 2018; 391: 82-94.

16. Chocair PR, Sabbaga E, Amato Neto V, Shiroma M, de Goes GM. Kidney transplantation: a new way of transmitting Chagas disease. Rev Inst med Trop Sao Paulo. 1981; 23: 280-282.

17. Pizzi T, de Croizet V, Smok G, Diaz M. Chagas's disease in a patient with renal transplantation and immunosuppressive treatment. Rev Med Chil. 1982; 110: 1207-1211.

18. Zayas CF, Perlino C, Caliendo A, Jackson D, Martinez EJ, Tso P, et al. Chagas disease after organ transplantation-United States, 2001. MMWR. 2002; 51: 210-212.

19. Barcan L, Luna C, Clara L, Sinagra A, Valledor A, De Rissio AM, et al. Transmission of T. cruzi infection via liver transplantation to a nonreactive recipient for Chagas'disease. Liver Transplant. 2005; 11: 1112-1116. 
20. Kun H, Moore A, Mascola L, Steurer F, Lawrence G, Kubak B, et al. Transmission of Trypanosoma cruzi by heart transplantation. Clin Infect Dis. 2009; 48: 1534-1540.

21. Huprikar S, Bosserman E, Patel G, Moore A, Pinney S, Anyanwu A, et al. Donor-derived Trypanosoma cruzi infection in solid organ recipients in the United States, 2001-2011. Am J Transplant. 2013; 13: 2418-2425.

22. Corey AB, Sonetti D, Maloney JD, Montgomery SP, Rademacher BL, Taylor $L$, et al. Transmission of donor-derived Trypanosoma cruzi and subsequent development of Chagas disease in a lung transplant recipient. Case Rep Infect Dis. 2017. article ID 5381072.

23. Riarte A, Luna C, Sabatiello R, Sinagra A, Schiavelli R, De Rissio A, et al. Chagas'disease in patients with kidney transplants: 7 years experience, 1989-1996. Clin Infect Dis. 1999; 29: 561-567.

24. Sousa A, Lobo MC, Barbosa RA, Bello V. Chagas seropositive donors in kidney transplantation. Transplant Proc. 2004; 36: 868-869.

25. Cicora F, Escurra V, Silguero S, Gonzalez IM, Roberti JE. Use of kidneys from Trypanosoma cruzi-infected donors in naive transplant recipients without prophylactic therapy: the experience in a high-risk area. Transplantation. 2014; 97: e3-e4.

26. Cura Cl, Lattes R, Nagel C, Gimenez MJ, Blanes M, Calabuig E, et al. Early molecular diagnosis of acute Chagas disease after transplantation with organs from Trypanosoma cruzi-infected donors. Am J Transplant. 2013; 13: 3253-3261.

27. D'Albuquerque LA, Gonzalez AM, Filho HL, Copstein JL, Larrea FI, Mansero JM, et al. Liver transplantation from deceased donors serologically positive for Chagas disease. Am J Transplant. 2007; 7: 680-684.

28. Salvador F, len O, Molina I, Sulleiro E, Sauleda S, Bilbao I, et al. Safety of liver transplantation with Chagas disease-seropositive donors for seronegative recipients. Liver Transplant. 2011; 17: 1304-1308.

29. McCormack L, Quinonez E, Golaracena N, Anders M, Rodriguez V, Orozco Ganem F, et al. Liver transplantation using Chagas-infected donors in uninfected recipients: a single-center experience without prophylactic therapy. Am J Transplant. 2012; 12: 2832-2837.

30. Balderramo D, Bonisconti F. Alcaraz A, Giordano E, Sanchez A, Barrabino M, et al. Chagas disease and liver transplantation: experience in Argentina using real-time quantitative PCR for early detection and treatment. Transplant Infect Dis. 2017; 19: e12782.

31. Casadei D and The Chagas'disease Argentine Collaborative transplant Consortium. Chagas'disease and solid organ transplantation. Transplant Proc. 2010; 42: 3354-3359.

32. da Costa AC, da Silva Filho JD, Rocha EA, Andrade MC, Vasconcelos Fidalgo AS, Almeida ERB, et al. Trypanosoma cruzi seroprevalence among solid organ donors in Ceara State, Brazil. Rev Soc Bras Med Trop. 2018; 51: 616-621.

33. Bocchi EA, Fiorelli $A$ on behalf of the First Guidelines Group for heart Transplantation of the Brazilian Society of Cardiology. The paradox of survival results after heart transplantation for cardiomyopathy caused by Trypanosoma cruzi. Ann Thorac Surg. 2001; 71: 1833-1838.

34. Stolf NAG, Higushi L, Bocchi E, Belotti G, Auler JO, Uip D, et al. Heart transplantation in patients with Chagas' disease cardiomyopathy. J Heart Lung Transplant. 1987; 6: 307-312.

35. Bocchi EA, Bellotti G, Uip D, Kalil J, de Lourdes Higuchi M, Fiorelli A, et al. Long-term follow-up after heart transplantation in Chagas'disease. Transplant Proc. 1993; 25: 1329-1330. 
36. de Carvalho VB, Souza FL, Vila JHA, Caiado MR, Araujo SR, Macruz R, et al. Heart transplantation in Chagas disease. 10 years after the initial experience. Circulation. 1996; 94: 1815-1817.

37. Bocchi EA, Bellotti G, Mocelin AO, Uip D, Bacal F, Higuchi ML, et al. Heart transplantation for chronic Chagas' heart disease. Ann Thorac Surg. 1996; 61: 1727-1733.

38. de Souza MM, Franco M, Almeida DR, Diniz RV, Mortara RA, da Silva S, et al. Comparative histopathology of endomyocardial biopsies in chagasic and non-chagasic heart transplant recipients. J Heart Lung Transplant. 2000; 220: 534-543.

39. Couto WJ, Branco JNR, Almeida D, Carvalho AC, Vick R, Teles CA, et al. Transplante cardiaco e infeccao. Rev Bras Cir Cardiovasc. 2001; 16: 141-151.

40. Fiorelli Al, Stolf NA, Honorato R, Bocchi E, Bacal F, Uip D, et al. Later evolution after cardiac transplantation in Chagas'disease. Transplant Proc. 2005; 37: 2793-2798.

41. Bacal F, Silva CP, Bocchi EA, Pires PV, Moreira LF, Issa VS, et al. Mychophenolate mofetil increased Chagas disease reactivation in heart transplanted patients: comparison between two different protocols. Am J Transplant. 2005; 5: 2017-2021.

42. Bestetti RB, Souza TR, Lima MF, Theodoropoulos TAD, Cordeiro JA, Burdmann EA. Effects of a mycophenolate mofetil-based immunosuppressive regimen in Chagas' heart transplant recipients. Transplantation. 2007; 84: 441-442.

43. Diez M, Favaloro L, Bertolotti A, Burgos JM, Vigliano C, lastra MP, et al. Usefulness of PCR strategies for early diagnosis of Chagas'disease reactivation and treatment follow-up in heart transplantation. Am J Transplant. 2007; 7: 1633-1640.

44. Campos SV, Strabelli TMV, Amato-Neto V, Silva CP, Bacal F, Bocchi EA, et al. Risk factors for Chagas'disease reactivation after heart transplantation. J Heart Lung Transplant. 2008; 27: 597-602.

45. Kransdorf EP, Czer LS, Luthringer DJ, Patel JK, Montgomery SP, Velleca A, et al. Heart transplantation for Chagas cardiomyopathy in the United States. Am J Transplant. 2013; 13: 3262-3268.

46. Gray EB, La Hoz RM, Green JS, Vikram HR, Benedict T, Rivera H, Montgomery SP. Reactivation of Chagas disease among heart transplant recipients in the United States, 2012-2016. Transplant Infect Dis. 2018; e12996.

47. Bern C. Chagas' disease in immunosuppressed hosts. Curr Opin Infect Dis. 2012; 25: 450-457.

48. Benatti RD, Al-Kindi SG, Bacal F, Oliveira GH. Heart transplant outcomes in patients with Chagas cardiomyopathy in the United States. Clin Transplant. 2018; 32: e13279.

49. Coster LO. Parasitic infections in solid organ transplant recipients. Infect Dis Clin N Am. 2013; 27: 395-427.

50. Ferraz AS, Figueiredo JFC. Transmission of Chagas'disease through transplanted kidney: occurrence of the acute form of the disease in two recipients from the same donor. Rev Inst Med Trop Sao Paulo. 1993; 35: 461-463.

51. Silva AE, Silva ACF, Faleiros ACG, de Oliveira Guimaraes CS, Correa RRM, Oliveira FA, et al. Acute Chagas'disease in postrenal transplant and treatment with benznidazole. Ann Diagn Pathol. 2010; 14: 199-203.

52. Cicora F, Escurra V, Bibolini J, Petroni J, Gonzalez I, Roberti J. Cerebral trypanosomiasis in a renal transplant recipient. Transplant Infect Dis. 2014; 16: 813-817. 
53. Amato JG, Neto VA, Amato VS, Duarte MIS, Uip DE, Boulos M. Lesoes cutaneas como unicas manifestacoes de ractivacao da infeccao pelo Trypanosoma cruzi em receptora de rim por transplante. Rev Soc Brasil Med Trop. 1997; 30: 61-63.

54. Gallerano V, Consigli J, Pereyra S, Zanni SG, Danielo C, Gallerano RH, Guidi A. Chagas 'disease reactivation with skin symptoms in a patient with kidney transplant. Int J Dermatol. 2007; 46: 607-610.

55. La Forgia MP, Pellerano G, Portaluppi M. Cutaneous manifestation of reactivation of Chagas disease in a renal transplant patient: long-term follow-up. Arch Dermatol. 2003; 139: 104-105.

56. de Campos FP, Pansard HM, Arantes LC, Rodrigues AT, Daubermann MF, Azambuja MF, et al. A case of Chagas'disease panniculitis after kidney transplantation. J Bras Nefrol. 2016; 18: 127-131.

57. Bestetti RB, Cury PM, Theodoropoulos TAD, Villafanha D. Trypanosoma cruzi myocardial infection reactivation presenting as complete atrioventricular block in a Chagas' heart transplant recipient. Cardiovasc Pathol. 2004; 13: 323-326.

58. Gomez-P CF, Mantill-H JC, Rodriguez-Morales AJ. Fatal Chagas disease among solid organ transplant recipients in Colombia. Open Forum Infect Dis. 2014; 1: ofu032. doi: 10.1093/ofid/ofu032.

59. Jackson Y, Dang T, Schnetzler B, Pascual M, Meylan P. Trypanosoma cruzi fatal reactivation in a heart transplant recipient in Switzerland. J Heart Lung Transplant. 2011; 30: 484-485.

60. Fiorelli AI, Santos RHB, Oliveira JL, Lourenco-Filho DD, Dias RR, Oliveira AS, et al. Heart transplantation in 107 cases of Chagas' disease. Transplant Proc. 2011; 43: 220-224.

61. Brasil PE, De Castro L, Hasslocher-Moreno AM, Sangenis LH, Braga JU. ELISA versus PCR for diagnosis of chronic Chagas disease: a systematic review and meta-analysis. BMC Infect Dis. 2010; 10: 337.

62. Dias JC, Ramos Jr AN, Gontijo ED, Luquetti A, Shikanai-Yasuda MA, Coura JR, et al. $2^{\text {nd }}$ Brazilian Consensus on Chagas disease, 2015. Rev Soc Bras Med Trop. 2016; 49: 3-60.

63. Benvenuti LA, Roggerio A, Cavalcanti MM, Nishiya AS, Levi JE. An autopsy-based study of Trypanosoma cruzi persistence in organs of chronic chagasic patients and its relevance for transplantation. Transplant Infect Dis. 2017; 19: e12783.

64. Andrade JP, Marin-Neto JA, Paola AA, Vilas-Boas F, Oliveira GM, Bacal F, et al.; Sociedade Brasileira de Cardiologia. I Latin American guideline for the diagnosis and treatment of Chagas' heart disease. Arq bras Cardiol. 2011; 97: 1-48.

65. WHO. Global leishmaniasis update, 2006-2015: a turning point in leishmaniasis surveillance. Wkly Epidem Rec. 2017; 38: 557-572.

66. Antinori S, Schifanella L, Corbellino M. Leishmaniasis: new insights from an old and neglected disease. Eur J Clin Microbiol Infect Dis. 2012; 31: 109-118.

67. Akhoundi M, Kuhls K, Cannet A. A historical overview of the classification, evolution, and dispersion of Leishmania parasites and sandflies. PLoS Neglect Trop Dis. 2016; 10: e0004349.

68. Antinori S, Cascio A, Parravicini C, Bianchi R, Corbellino M. Leishmaniasis among organ transplant recipients. Lancet Infect Dis. 2008; 8: 191-199.

69. Postorino MC, Bellantoni M, Catalano C, Caridi G, De Rosa M, Seck S, et al. Visceral leishmaniasis reactivation in transplant patients: a minireview with report of a new case. J Nephrol. 2011; 24: 530-534. 
70. Ramos A, Munez E, Garcia-Dominguez J, Martinez-Ruiz R, Chicarro C, Banos I, et al. Mucosal leishmaniasis mimicking squamous cell carcinoma in a liver transplant recipient. Transplant Infect Dis. 2015; 17: 488-492.

71. Baglieri F, Scuderi G. A case of mucosal leishmaniasis of the tongue in a kidney transplant recipient. Int J Dermatol. 2012; 51: 597-600.

72. Vinhal FA, Afonso-Cardoso SR, Silva AG, Pereira CG, Sousa W, Botelho SM, et al. A typical presentation of cutaneous leishmaniasis after renal transplantation. Nephrol Dial Transplant. 2007; 22: 3674.

73. Maggi P, Gaudiano V, Valente M, Latorraca A, Cavaliere RL, Marroni M, et al. Leishmaniasis in patients with chronic renal failure: a diagnostic and therapeutic challenge for the clinician. J Nephrol. 2004; 17: 296-301.

74. Souza RM, de Oliveira IB, Paiva VC, Lima KC, dos Santos RP, de Almeida JB, et al. Presence of antibodies against Leishmania chagasi in haemodialysed patients. Trans R Soc Trop Med Hyg. 2009; 103: 749-751.

75. Akuffo H, Costa C, van Griensven J, Burza S, Moreno J, Herrero M. New insights into leishmaniasis in the immunosuppressed. Plos Neglect Trop Dis. 2018; 12: e0006375.

76. Clemente WT, Rabello A, Faria LC, Peruhype-Magalhaes V, Gomes LI, da Silva TA, et al. High prevalence of asymptomatic Leishmania spp. infection among liver transplant recipients and donors from an endemic area of Brazil. Am J Transplant. 2014; 14: 96-101.

77. Fitzpatrick MA, Caicedo JC, Stosor V, Ison MG. Expanded infectious diseases screening program for Hispanic transplant candidates. Transplant Infect Dis. 2010; 12: 336-341.

78. Elmahallawy EK, Cuadros-Moronta E, Liebana-Martos MC, Rodriguez-Granger JM, SampedroMartinez A, Agil A, et al. Seroprevalence of Leishmania infection among asymptomatic renal transplant recipients from Southern Spain. Transplant Infect Dis. 2015; 17: 795-799.

79. Clemente W, Vidal E, Girao E, Ramos ASD, Govedic F, Merino E, et al. Risk factors, clinical features and outcomes of visceral leishmaniasis in solid-organ transplant recipients: a retrospective multicenter case-control study. Clin Microbiol Infect. 2015; 21: 89-95.

80. Carrasco-Anton N, Lopez-Medrano F, Fernandez-Ruiz M, Carrillo E, Moreno J, Garcia-Reyne A, et al. Environmental factors as key determinants for visceral leishmaniasis in solid organ transplant recipients, Madrid, Spain. Emerg Infect Dis. 2017; 23: 1155-1159.

81. de Silva AA, Silva Filho APE, Cinta Sesso R C, Matos Esmeraldo R, de Oliveira CMC, Fernandes $\mathrm{PF}$, et al. Epidemiologic, clinical, diagnostic and therapeutic aspects of visceral leishmaniasis in renal transplant recipients: experience from thirty cases. BMC Infect Dis. 2015; 15: 96.

82. Pereira CM, Oliveira HM, Lopes V, Gandara J, Ferreira S, Daniel J, Miranda HP. Visceral leishmaniasis after orthotopic liver transplantation: a rare cause of infection. Transplant Infect Dis. 2016; 18: 251-254.

83. Basset D, Faraut F, Marty P, Dereure J, Rosenthal E, Mary C, et al. Visceral leishmaniasis in organ transplant recipients: 11 new cases and a review of the literature. Microbes Infect. 2005; 7: 1370-1375.

84. Frapier JM, Abraham B, Dereure J, Albat B. Fatal visceral leishmaniasis in a heart transplant recipient. J Heart Lung Transplant. 2001; 20: 912-913.

85. Desoubeaux G, Guery EA, Dujardin F, Feau-Lecerf S, Perarnau JM, Bailly E, et al. Digestive bleeding in a Georgian liver transplant recipient. Clin Infect Dis. 2015; 60: 1131-1133. 
86. Yucel S, Ozcan D, Seckin D, Allahverdiyev AM, Kayaselcuk F, Haberal M. Visceral leishmaniasis with cutaneous dissemination in a renal transplant recipient. Eur J Dermatol. 2013; 23: 892893.

87. Gontijo CM, Pacheco RS, Orefice F, Lasmar R, Silva ES, Melo MN. Concurrent cutaneous, visceral and ocular leishmaniasis caused by Leishmania (Viannia) braziliensis in a kidney transplant patient. Mem Inst Oswaldo Cruz. 2002; 97: 751-753.

88. Ozcan D, Seckin D, Allahverdiyvev AM, Weina PJ, Aydin H, Ozcay F, et al. Liver transplant recipient with concomitant cutaneous and visceral leishmaniasis. Pediatr Transplant. 2007; 11: 228-232.

89. Vinhal FA, Afonso-Cardoso SR, Silva AG, Pereira CG, Sousa W, Botelho SM, et al. A typical presentation of cutaneous leishmaniasis after renal transplantation. Nephrol Dial Transplant. 2007; 22: 3674.

90. Yaich S, Charfeddine K, Masmoudi A, Masmoudi M, Zaghdhane S, Turki H, et al. Atypical presentation of cutaneous leishmaniasis in a renal transplant recipient successfully treated with allopurinol and fluconazole. Ann Saudi Med. 2013; 33: 187-191.

91. Borgia F, Vaccaro M, Guarneri F, Manfre C, Cannavo SP, Guarneri C. Mucosal leishmaniasis occurring in a renal transplant recipient. Dermatology. 2001; 202: 266-267.

92. Baglieri F, Scuderi G. A case of mucosal leishmaniasis of the tongue in a kidney transplant recipient. Int J Dermatol. 2012; 51: 597-600.

93. Tuon FF, Bombonatto GM, Battaglin ER, Sakumoto ME, Amato VS, de Camargo RA, et al. Case report: reactivation of mucosal and cutaneous leishmaniasis in a renal transplanted patient. Am J Trop Med Hyg. 2014; 91: 81-83.

94. Ramos A, Munez E, Garcia-Dominguez J, Martinez-Ruiz R, Chicarro C, Banos I, et al. Mucosal leishmaniasis mimicking squamous cell carcinoma in a liver transplant recipient. Transplant Infect Dis. 2015; 17: 488-492.

95. Simon I, Wissing KM, Del Marmol V, Antinori S, Remmelink M, Nilufer Broeders E, et al. Recurrent leishmaniasis in kidney transplant recipients: report of 2 cases and systematic review of the literature. Transplant Infect Dis. 2011; 13: 397-406.

96. de Ruiter CM, van der Veer C, Leeflang MM, Deborggraeve S, Lucas C, Adams ER. Molecular tools for diagnosis of visceral leishmaniasis: systematic review and meta-analysis of diagnostic test accuracy. J Clin Microbiol. 2014; 52: 3147-3155.

97. Opota O, Balmpouzis Z, Berutto C, Kaiser-Guignard J, Greub G, Aubert J-D, et al. Visceral leishmaniasis in a lung transplant recipient: usefulness of highly sensitive real-time polymerase chain reaction for preemptive diagnosis. Transplant Infect Dis. 2016; 18: 801-804.

98. Vega Benedetti F, Cimino RO, Cajal PS, Juarez MDV, Villalprando CA, Gil JF et al. Performance of different Trypanosoma cruzi antigens in the diagnosis of Chagas disease in patients with American cutaneous leishmaniasisfrom co-endemic region in Argentina. Trop Med Int Health. 2013; 18: 1103-1109.

99. Schwartz BS, Mawhorter SD, AST Infectious Diseases Community of Practice. Parasitic infections in solid organ transplantation. Am J Transplant. 2013; 13: 280-303.

100. Aronson N, Herwaldt BL, Libman M, Pearson R, Lopez-Velez R, Weina P, et al. Diagnosis and treatment of Leishmaniasis: clinical practice guidelines by the Infectious Diseases Society of America (IDSA) and the American Society of Tropical Medicine and Hygiene (ASTMH). Clin Infect Dis. 2016; 63: 1539-1557. 
101. Perez-Jacoiste Asin MA, Carrasco-Anton N, Fernandez-Ruiz M, San Juan R, Alonso-Moralejo R, Gonzalez $\mathrm{E}$, et al. Experience with miltefosine for persistent or relapsing visceral leishmaniasis in solid organ transplant recipients: a case series from Spain. Transplant Infect Dis. 2017; 19: e12623.

102. Antinori S, Galimberti L, Milazzo L, Corbellino M. Plasmodium knowlesi: the emerging zoonotic malaria parasite. Acta Trop. 2013; 125: 191-201.

103. Verra F, Angheben A, Martello E, Giorli G, Operandi F, Bisoffi Z. A systematic review of transfusion-transmitted malaria in non-endemic areas. Malar J. 2018; 17: 36.

104. Olupot-Olupot P, Eregu EIE, Naizuli K, Ikiror J, Acom L, Burgoine K. Neonatal and congenital malaria: a case series in malaria endemic eastern Uganda. Malar J. 2018; 17: 171.

105. Bick RL, Anhalt JE. Malaria in drug addicts. JAMA. 1971; 216: 1036.

106. Coster LO. Parasitic infections in solid organ transplant recipients. Infect Dis Clin N Am. 2013; 27: 395-427.

107. Fischer L, Sterneck M, Claus M, Costard-Jackle A, Fleischer B, Herbst $H$, et al. Transmission of malaria tertiana by multi-organ donation. Clin Transplant. 1999; 13: 491-495.

108. Ladeb S, Abdejlil NB, Fakhfakh N, Lakhal A, Belloumi D, Hamed LB, et al. Plasmodium falciparum infection transmitted by transfusion: a cause of hemophagocytic syndrome after bone marrow transplantation in a non-endemic country. Transplant Infect Dis. 2018; e12887.

109. Luethy PM, Murphy SC, Seilie AM, Xie YL, Lau C-Y, Tisdale JF, et al. Diagnostic challenges of prolonged post-treatment clearance of Plasmodium nucleic acids in a pre-transplant autosplenectomized patient with sickle cell disease. Malar J. 2018; 17: 23.

110. O'Brien SF, Delage G, Seed CR, Pillonel J, Fabra CC, Davison K, et al. The epidemiology of imported malaria and transfusion policy in 5 nonendemic countries. Transf Med Rev. 2015; 29: 162-171.

111. Len O, Garzoni C, Lumbreras C, Molina I, Meije Y, Pahissa A, Grossi P on behalf of the ESCMID Study Group of infection in compromised hosts (ESGICH). Recommendations for screening of donor and recipient prior to solid organ transplantation and to minimize transmission of donor-derived infections. Clin Microbiol Infect. 2014; 20: 10-18.

112. Pandey D, Lee KH, Wong SY, Tan KC. Malaria after living donor liver transplantation: report of two cases. Hepatobiliary Pancreat Dis Int. 2008; 7: 210-213.

113. Mejia GA, Alvarez CA, Pulido HH, Ramirez B, Cardozo C, Suarez Y, et al. Malaria in a liver transplant recipient: a case report. Transplant Proc. 2006; 38: 3132-3134.

114. Martin-Davila P, Norman F, Fortun-Abate J, Piris M, Lovatti R, Rubio JM, et al. Donor-derived multiorgan transmission of mixed $P$. malariae and $P$. ovale infection: impact of globalization on post-transplant infections. Transplant Infect Dis. 2018; 20: e12938.

115. Chiche L, Lesage A, Duhamel C, Salame E, Mallet M, Samba D, et al. Posttransplant malaria: first case of transmission of Plasmodium falciparum from white multiorgan donor to four recipients. Transplantation. 2003; 75: 166-168.

116. Cruz I, Mody V, Callender C, Hosten A. Malaria infection in transplant recipient. J Natl Med Ass. 1978; 70: 105-107.

117. Pierrotti LC, Kotton CN. Transplantation in the tropics: lessons on prevention and management of tropical infectious diseases. Curr Infect Dis Rep. 2015; 17: 492. 
118. Sabé N, Gonzalez-Costello J, Oriol I, Sanchez-Salado JC, Ortega S, Oliver E, et al. Donortransmitted malaria after heart transplant managed successfully with artesunate. Transplant Infect Dis. 2014; 16: 999-1002.

119. Nuesch R, Cynke E, Jost M-C, Zimmerli W. Thrombocytopenia after kidney transplatation. Am J Kidney Dis. 2000; 35: 537-538.

120. Menichetti F, Bindi ML, Tascini C, Urbani L, Biancofiore G, Doria R, et al. Fever, mental impairment, acute anemia, and renal failure in patient undergoing orthotopic liver transplantation: posttransplantation malaria. Liver Transplant. 2006; 12: 674-676.

121. Set AK, Puri P, Chandra A, Dutta V, Naidu S, Saha A. Mixed Plasmodium falciparum and Plasmodium vivax malaria in orthotopic liver transplant recipient. Transplantation. 2009; 88: 288.

122. Rodriguez M, Tome S, Vizcaino L, Fernandez-Castroagudin J, Otero-Avila E, Molina E, et al. Malaria infection through multiorgan donation: an update from Spain. Liver Transplant. 2007; 13: $1302-1304$.

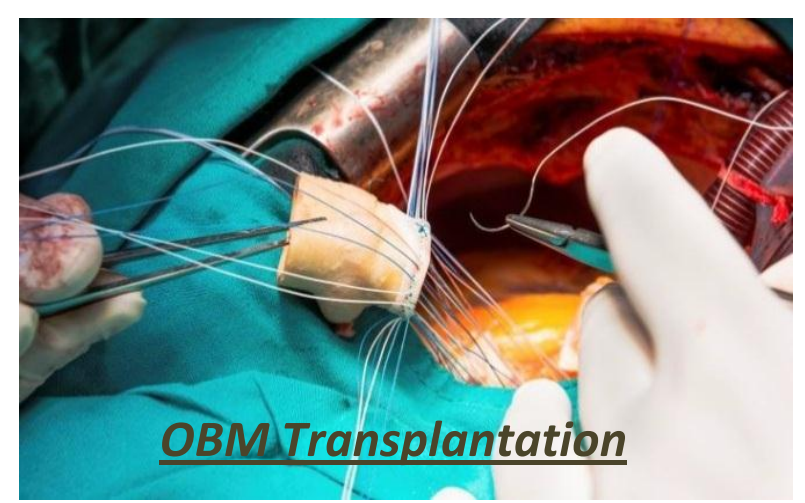

Enjoy OBM Transplantation by:

1. Submitting a manuscript

2. Joining in volunteer reviewer bank

3. Joining Editorial Board

4. Guest editing a special issue

For more details, please visit:

http://www.lidsen.com/journals/transplantation 